Politik Ekonomik Kuram 2018, Cilt 2(1), 87-102

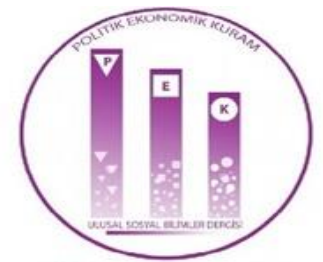

Cilt 2(1) 2018
Politik Ekonomik Kuram Dergi Web Sitesi: http://dergipark.gov.tr/pek

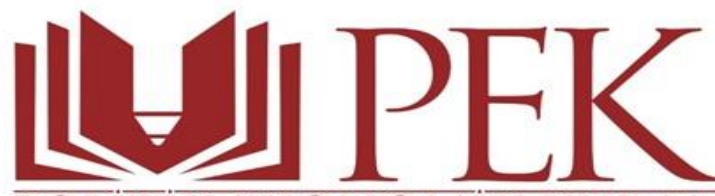
POLITIK EKONOMIK KURAM

\title{
Yeni Anayasa Tartışmaları ve Hükümet Sistemi Arayışları ${ }^{1}$
}

\section{Mehmet ARI ${ }^{2}$}

\section{Makale Bilgileri}

Makale Geçmişi:

Makalenin Yüklendiği Tarih: 28.02.2018

Makalenin Kabul Edildiği Tarih: 12.03.2018

Jel Kodlar1: Y80, Z18, R58

Anahtar Kelimeler: Demokrasi, Siyasal Sistem, Anayasa Tartışmaları

\begin{abstract}
Özet
Antik Yunan'dan modern zamanlara, siyasal rejimlerin niteliği ve demokrasi siyasal düşüncenin ve siyaset felsefesinin temel tartışmalarından biri olagelmiştir. Parlamenter sistem ve başkanlık sistemlerinden hangisinin daha demokratik ve daha katılımcı olduğu yönündeki tartışmalar ise günümüzde halen devam etmektedir. Türkiye'de de bir süredir "Türk tipi başkanlık” adı altında bir sistem değişikliği süreci yaşanmakta, parlamenter sistemden “Türkiye’ye özgü” olduğu söylenen bir başkanlık sistemine geçiş için adımlar atılmaktadır. Bu çalışmanın amacı, siyasal düşüncedeki rejim, demokrasi, parlamenter sistem ve başkanlık sistemi tartışmalarının ışığında, söz konusu rejim değişikliği sürecini eleştirel bir perspektifle değerlendirmek ve aynı zamanda "demokratikleşme" perspektifli anayasal bir alternatif öneri sunmaktır.
\end{abstract}

\section{Anahtar Sözcükler: Demokrasi, Siyasal Sistem, Anayasa Tartışmaları}

The New Constitutional Debate and the Search for Government System

\section{Abstract}

From Ancient Greece to modern age, the nature of political regimes and democracy has been the most important discussion in political thought and political philosophy. Nowadays, the discussions has been continuing on parliamentarism and presidential system. In these discussions, the main issue is to clarify the question of which system is the most democratic and participatory. Recently, a key issue on the political agenda concerns a transition from parliamentarism to presidentialism named as 'Turkishstyle presidential system". The purpose of this study is to examine and analyse this transformation process in political regime, in consideration of the main debates on political regime, democracy, parliamentary system and presidential system, from a critical perspective and also to suggest an constitutional alternative based on democratisation perspective.

\section{Key words: Democracy, Political system, Constitutional Debate}

\footnotetext{
1 4-6 Aralık 2013 tarihinde gerçekleştirilen 13. Ulusal Sosyal Sosyal Bilimler Kongresi'nde sunulan bildiriye dayanmaktadır.

${ }^{2}$ Yrd. Doç. Dr. Abant İzzet Baysal Üniversitesi, İIBF, Kamu Yönetimi Bölümü, mehmetari2002@gmail.com
} 


\section{Giriş}

Hükümet sistemleri demokratik olanlar ve olmayanlar şeklinde ayrılabilir. Bu ayrım Platon ve Aristoteles'in yönetimleri ayırmasına benzetilebilir. Hepimizin bildiği üzere Platon ve Aristoteles demokrasiyi benimsemezler. Platon ve Aristoteles rejimleri yönetici sayısına (yürütmenin yapısına) göre üçe ayırıyor. $\mathrm{Bu}$ rejimlerin bozulmuş halleriyle sayı altıya yükseliyor. Bu rejimler monarşi, aristokrasi ve demokrasi ile bunların bozulmuş biçimi olan tiranlık, oligarşi ve yasasız (aşırı) demokrasidir (Ağaoğulları, 2004: 226-357). Platon'a göre, demokrasilerde yurttaşlar yetenekli olup olmadıklarına, politika sanatını bilip bilmediklerine bakılmaksızın seçimle ve çoğu kez kurayla devletin başına getirilirler. Bu durum, gemicilikten ya da hekimlikten hiç anlamayan cahil kişilerden, zanaatkârlardan bir gemiyi yürütmesini ya da bir hastayı iyileştirmesini beklemek kadar saçmadır. Üstelik vereceği zarar daha da büyüktür. Çünkü cahil kaptan ile cahil hekim, birkaç kişinin yaşamı ile oynarlar; oysa demokraside devleti yönetenler bütün polisin, yurttaşların hepsinin yaşamını tehlikeye atarlar(Ağaoğulları, 2004: 226-227). “Aristoteles'in yaklaşımı da demokrasiyi benimsemez ama Platon'dan farklılaşır. Aristoteles, demokrasinin farklı türlerini açıklayabilmek için Atina demokrasisinin Solon'dan başlayarak inişli çıkışlı bir biçimde geçirdiği çeşitli evreleri incelemiş ve bu incelemelerinden yararlanmıştır. Aristoteles'in demokrasiyi çeşitli türlere ayırmakla güttüğü temel amaç, dolaylı bir biçimde, Solon'un anayasasını ya da Peloponnesos Savaşları döneminde, 411 yılında yurttaş sayısını 5.000 kişiye indiren anayasayı, demokratik olarak ve hatta en iyi demokrasi biçimleri olarak gösterip kafaları bulandırmak ve dönemindeki demokrasileri karalamaktı. Böylece 1lımlı oligarşiler, Aristoteles'in kaleminde en iyi demokrasilere dönüşmüş ve demokratlara ulaşılması gereken birer örnek olarak sunulmuş oluyordu. Demokrasilerin yıkılmasını önlemeye yönelik olarak ileri sürdüğü "devlet görevlilerinin seçiminde bütün halkın değil, kabilelerin seçmen yapılması" önerisi, Aristoteles'in bu amacını açık bir biçimde gözler önüne sermektedir"(A ğaoğulları, 2004: 363).

17. yüzyıl siyasal düşüncenin gelişimi açısından modern dönemin başlangıcı sayılır. Ulusal devletin gelişmekte olduğu bu çağda önemli bir düşünür olarak John Locke'un yönetim biçimleri hakkındaki görüşlerine değinilmelidir. "Locke yönetim biçimlerini yasama yetkisini kullananlara göre dörde ayırır. Toplum yasama yetkisini kimin kullanacağını çoğunluk kararıyla belirler. Buna göre; toplum yasama yetkisini kendisi kullanırsa demokrasi, belirli bir kesime ve onların mirasçılarına bırakırsa oligarşi, tek bir kişiye bırakırsa monarşi, bu kesimler 
arasında paylaştırırsa karma yönetim söz konusudur’(Uygun, 2014: 224). Bu yönetim biçimlerinin hepsi meşru ve toplum sözleşmesine uygun yetki kullanırlar. Sözleşmenin belirlediği sınırları aşarlarsa meşruluklarını yitirirler ve direnme hakkı doğar.

18. yüzyıl düşünürlerinden Montesquieu da Platon ve Aristoteles'in yaptığına benzer bir tasnifi savunmaktadır. Ancak Montesquieu'nun ayırıcı yanı bu rejimlerden birini tercih etmemesidir. Montesquieu'ya göre Platon ve Aristoteles'in tercih ettiği gibi rejimleri kategorik olarak iyi ve kötü olarak ayıramayız. "Hangi rejim iyidir" sorusunu cevaplayabilmemiz için "hangi millet için bir rejim arıyoruz" sorusunu cevaplamamız gerekmektedir. Yani rejimlerin işlerliği ve yararlılığı milletin çeşitli özellikleriyle ilişkili ve uyumludur. Bugün için bu yorum kabul edilemez gözükse de, rejim tartışmalarında sıklıkla ülkelerin siyasal ve sosyal yapılarının ve kültürlerinin farklılıklarına değinilmektedir.

Bu kısa özetten günümüz demokrasi tartışmalarına geçilirse, demokratik rejim farklı hükümet sistemleri ile gerçekleştirilebilir.

Demokratik rejimin gerçekleştirildiği hükümet sistemleri temelde ikiye ayrılmaktadır: sert kuvvetler ayrılığı uygulanan başkanlık sistemi ile yumuşak kuvvetler ayrımının uygulandığı parlamenter sistem. Üçüncü bir demokratik hükümet sistemi ise yarı-başkanlık (yar1parlamenter) sistemidir.

Birkaç özelliğiyle bu sistemlerin uygulandığı ve başarıları dolayısıyla modellerin temsilcisi olarak gösterilen ülkelerdeki gelişimlerine ve genel özelliklerine değinerek Türkiye’nin siyasal rejim ve hükümet sistemi tartışmalarına geçebiliriz.

\section{Parlamenter Sistem}

Parlamenter sistem yasama yürütme ilişkileri açısından yumuşak kuvvetler ayrılığı olarak adlandırılan bir sistemdir. Asli özelliklerini sıralarsak; 1) Yürütme organı iki başlıdır. Yürütmenin sorumsuz kanadı olarak devlet başkanı ve sorumlu kanadı olarak bakanlar kurulu vardır(Gözler, 2015: 92). 2) Parlamenter sistemlerde yürütme organı parlamento içinden seçilen ve parlamentoya karşı sorumlu olan bakanlar kuruludur. Bakanlar kurulunun başkanı parlamento içinden seçilen başbakandır(Teziç, 2001: 404). 3) Devlet başkanının 
sorumsuzluğunun temelinde yürütme yetkisinin bakanlar kurulunda olması vardır. Bu yüzden devlet başkanının yürütmeye ilişkin işlemleri başbakan ve ilgili bakan tarafından imzalanır (Gözler, 2015, 92).

$\mathrm{Bu}$ asli özellikleri değerlendirecek olursak, devlet başkanının yürütme işleriyle ilgili olarak yetkisiz ve sorumsuz olması onu sistem içinde sembolik bir konuma getirir. Ancak onun bu yetkisiz ve sorumsuzluk hali bir avantaj olarak da kullanılabilmekte, kriz zamanlarında onun meclisteki partiler arasında işbirliğinin yolunu açan bir aktör olarak sistemin krizden çıkmasına katkı sağladığı görülmektedir ya da Türkiye örneğinde olduğu gibi beklenmektedir.

Yürütmenin sorumlu ve yetkili kanadının parlamento içinden çıkması ve parlamentoya karşı sorumlu olması kuvvetler ayrılığı ilkesinin yumuşak bir uygulamasına dikkat çekmektedir. Demokrasilerde gücün kaynağı olarak millete (halka) işaret edilmesi, doğrudan halkın seçimiyle oluşan parlamentoya bir meşruiyet sağlamaktadır. Bu parlamentodan çıkan hükümet ise dolaylı bir meşruiyete sahip olmaktadır. Bu çerçevede düşündügüumüzde parlamento tarafından seçilsin veya seçilmesin devlet başkanının gücü de parlamento üstünde bir güç değildir.

Yukarıda belirttiğimiz parlamentonun halkın seçiminden kaynaklanan gücü uygulamada, parlamenter sistemlerde karşılaştığımız parti disiplini dolayısıyla partilerin ve liderlerinin gücüyle tanımlanmaktadır. Parlamentoda güçlü olan ve parlamento çoğunluğuna sahip olan partinin isteği doğrultusunda hükümetin oluşumu ve yasama faaliyetleri şekillendiğinden, parlamentonun hükümet üzerindeki denetleme yetkisi tartışmalı hale gelmektedir. Bu noktada hükümetin denetlenmesinin yolu olarak muhalefetin önemine değinen Cem Eroğul, İngiltere örneğini verir: "Seçimlerde ikinci duruma gelen partiye resmi bir muhalefet görevi yükleyerek, çoğunluğun denetimsiz kalmamasını sağlamışlardır. Bugün İngiltere'de muhalefet öylesine güven içinde çalışma olanağına sahiptir ki, birçok yazarın gözünde muhalefetin bu durumu demokrasinin varlık koşulu haline gelmiştir”(Eroğul, 2005: 53). İngiltere'de parlamentonun doğuşu ve gelişimi kısaca şöyle özetlenebilir: 1215 Magna Carta Libertatum ile başlayan, kralın vergi koyma yetkisine ortak olmak isteyen soyluların itiraz etmesiyle başlayan süreç parlamentonun oluşumunun başlangıcıdır. 1295 yılında "Model Parlamento" olarak adlandırılan parlamentoda baronlar, kontlar ve ruhban sınıfının dışında, kontlukların, şehirlerin ve burgların temsilcileri ile küçük rahiplerin temsilcileri de vardı. Bu Model Parlamento, İngiltere'de parlamentonun kuruluşunun kesin tarihi kabul edilir. Bu tarihten beri parlamento 
devamlı olarak varlığını sürdürmüştür (Gözler, 2013: 331-332). Parlamentonun yasama yetkisini ele geçirmesi ise uzun bir sürecin sonunda 1689 tarihli Bill of Rights (Haklar Beyannamesi) ve 1701 tarihli Act of Settlement'ın kabulü ile gerçekleşmiştir (Gözler, 2013: $335)$.

$\mathrm{Bu}$ noktada güçlü bir parlamento desteğine sahip hükümetin sistemi parlamentodaki muhalefetin etkisiz hale geldiği bir sisteme dönüştürdüğünü görebiliriz. Bu vurgumuzun sebebi parlamenter sistemin bir avantajı olarak muhalefetin varlığı hem sorunların çözümüne katk1 sağlar, hem de sistemin kilitlenmesini önler. Ayrıca muhalefetin varlığı ve etkililiği demokrasi ile ilişkilendirilebilir. Demokrasinin temel özelliklerini çoğunluğun yönetimi ve azınlığın çoğunluk olma olanağının ve olasılığının kabulü ile başlatabiliriz. Buna ek olarak demokrasinin olmazsa olmazlarından bir diğerinin hukuk devleti olduğunu belirtmeliyiz. Hukuk devletinin önemi azınlığın yani muhalefetin varlığının bir güvencesi olarak görülmelidir. Ayrıca hukuk devleti ilkesinin geçerliliği iktidar açısından da bir avantajdır. İktidarın hukuk ihlallerinin önlenmesi, demokratik sistemin, muhalefetin olduğu kadar iktidarın da yararınadır. Böyle bir ortam sistem dişı muhalefetin önünü keser ve demokrasinin sürekliliğini sağlarken bireyler açısından da demokratik bir rejimde yaşamanın güvencesi olur.

\section{Başkanlık Sistemi}

Başkanlık sisteminin Amerika Birleşik Devletleri'nin hükümet sistemi olmasından yola çıkılarak ilk belirlenen özelliği, İngiliz hükümet sistemi olan parlamenter sistemin aksine geleneklerin ve tarihin yarattığı bir sistem olmayıp insanların akıllarıyla ortaya çıkardığı bir sistem olmasıdır(Teziç, 2001: 427). Buradan yola çıkarak başkanlık sistemini ülkemize hükümet sistemi olarak öneren Burhan Kuzu’nun görüşüne değinebiliriz: “İnsan aklının bulduğu ve geliştirdiği bir model olduğundan her ülkenin insanları oturup kendi ülkesinin şartlarını da dikkate alarak pekâlâ ülkelerine özgü bir başkanlık modeli oluşturabilir’'(Kuzu, 2012: 19). Başkanlık sisteminin Dünya'da ilk ve özgün modelini oluşturan Amerika Birleşik Devletleri tipi bir başkanlık rejiminin başka hiç bir ülkede demokratik olarak işlemediği vurgulanmaktadır(Teziç, 2001: 424). Yani başkanlık sistemini kurmaktan daha zor olanı demokratik bir rejim kurmaktır. 
Başkanlık sisteminin temel özellikleri: 1) Yürütmenin tek kişiden oluşması, 2) Başkanın, doğrudan doğruya veya doğrudan benzeri bir biçimde halk tarafından seçilmesi, 3) Belli bir dönem için seçilen yürütmenin yasamanın güvenine dayanmaması.

Bu özellikleri kısaca gözden geçirelim:

1. Yürütmenin tek kişiden oluşması. Başkanlık sisteminde yürütme görevini tek başına gerçekleştirmek üzere bir başkan seçilmektedir. "Hem devlet başkanı, hem de yürütmenin başı olarak, elinde parlamenter dizgede asla düşünülemeyecek bir yetki birikimi bulunuyor. Amerikan siyasal dizgesine başkanlık dizgesi denmesinin nedeni de bu. Anayasa yapılırken başkanın böylesine büyük bir güç olacağı öngörülmemişti. Ancak anayasada bunu engelleyen bir hüküm de yoktu. Zamanla, ABD güçlendikçe, özekselleşmenin (merkezileşmenin) doğal sonucu olarak başkan da güçlendi”(Eroğul, 2008: 104).

$\mathrm{Bu}$ çerçevede başkanın yetkilerinin belirsizliğine değiniliyor ve açıkça belirlenmiş yetkileri sıralanıyor: "1. Başkomutanlık. 2. Antlaşmaları imzalama ve yüksek düzeydeki federal görevlileri atama. 3. Kongreye bir yasam izlencesi (yasa tasarıları değil) sunabilme. 4. Kongreyi ya da meclislerden birini toplantıya çağırma. 5. Veto. 6. Yasaları uygulama" (Eroğul, 2008: 107).

$\mathrm{Bu}$ yetkilerine dayanarak yürütme görevini yerine getirirken, başkan belirli konularda sekreterler görevlendirmektedir. Parlamenter sistemde bakanlara karşılık geldiği kabul edilen bu sekreterlerin politik ve idari anlamda bütün yetkileri tek başına yürütmeyi oluşturan başkandan kaynaklanmaktadır. Yani yetkiler başkana aittir. Dolayısıyla başkan gibi bakanlar da yasama tarafından yetkilendirilmezler.

\section{Başkanın doğrudan doğruya veya doğrudan benzeri bir yöntemle halk tarafından}

seçilmesi. Başkan belirli bir süre için ve bu sürenin sonuna kadar görevden alınamama koşuluyla halk tarafından seçilir. "Yürütmenin başının halk tarafından seçilmesi tartışmasız bir biçimde sistemin zorunlu özelliğidir. Başkanlık sisteminde, yürütme organı da tıpkı yasama organı gibi, meşruluğunun kaynağını doğrudan halkta bulur”(Uluşahin, 1999: 30-31). Dolayısıyla başkanlık sisteminde yürütmenin meşruiyeti parlamenter rejimde olduğu gibi parlamento dolayımından geçmez. 
Başkanı güçlü kılan ve süre garantisi dolayısıyla başkanlık sisteminin siyasal istikrarın garantisi gibi görülmesine yol açan bu özellik, öte yandan rejimin kilitlenmesinde de temel etken olarak görülür. Kongrenin ve başkanın ayrı ayrı halkın meşruiyetine dayanması ve birbirlerine dönük kontrol mekanizmasının olmaması temel etkendir. Yürütmenin yasamayı fesih yetkisi olmadığı gibi, yasamanın da yürütmeyi görevden alma yetkisi yoktur. Bu durumda iki organ iki farklı siyasal eğilim tarafından kazanıldığında sistemin kilitlenmesi adeta kaçınılmaz olmaktadır(Kalaycığlu, 2005: 25).

Amerikan başkanlık sisteminin yukarıda değindiğimiz kilitlenme sorununu yaşamamasının veya kolay atlatabilmesinin nedeni olarak Amerikan deneyiminin özgünlükleri gösterilmektedir. Örneğin Amerika'da siyasal parti disiplini olmaması en sık vurgulanan bir özelliktir(Polatoğlu, 2013: 7). Başkanın siyasal partisi ile kongre çoğunluğu farklı partilerden olsa bile Amerikan siyasal kültüründe belirleyici bir özellik olarak gösterilen, pragmatik davranan temsilciler başkan ile kongre arasında doğabilecek krizi çözebiliyorlar. Ayrıca Amerika Birleşik Devletleri başkanlık sisteminde devlet hayatının felce uğramasını önleyici karşılıklı etkileşim araçları geliştirilmiştir. “Örneğin, yürütme görevlerine Başkanın yapacağı atamalar, Senatoca onaylanır; yürütmenin yaptığı uluslararası andlaşmaların da Senatoca üçte iki çoğunlukla onaylanması gerekir. Buna karşılık, Başkanın da, Kongreden geçen yasaları 'veto' etme yetkisi vardır. Vetodan sonra tasarının yasalaşabilmesi için, her iki Meclisce üçte iki çoğunlukla kabul edilmesi gerekir”(Gözübüyük, 2011: 40) . Bu karşılıklı yetkilerin amacı, organların bağımsızlı̆̆ı değil, birbirleriyle işbirliği yapmalarını, uyum içinde çalışmalarını sağlamaktır. Bu nedenle Amerika Birleşik Devletleri sistemine "frenler ve dengeler" sistemi denmektedir (Gözler, 2013: 237).

ABD başkanlık rejiminin sorunları çözebilmesinin bir başka nedeni ise sistemin federal bir sistem olmasına bağlanabilir. Burada kastedilen, federal bir devlette var olan eyaletlerin (federe devletler), bütün siyasal organlarıyla bir devlet niteliği taşımasıdır. Dolayısıyla her Amerikan vatandaşı bir federe devlette yaşamaktadır ve günlük hayatına ilişkin devletle karşılaştı̆̆ yer federe devlet ve orada uygulanan politikalar olmaktadır. Bu sebeple başkanın hangi siyasal partiye mensup olduğu, vatandaş açısından sınırlı bir önem taşımaktadır. Türkiye' de başkanlık rejimi tartışmaları başkanlık sisteminin federalizme yol açacağı varsayımıyla tartışılmaktadır. $\mathrm{Bu}$ da bazı siyasal partiler açısından bölünme projesi olarak değerlendirilmektedir. Başkanlık sisteminin federal bir yapıyla uygulanması zorunlu olmadığı gibi, federal yapıya sahip 
parlamenter demokrasiler de mevcuttur(Gülalp, 2013: 198). Örneğin Almanya parlamenter sistem uygulayan federal bir devlet iken, Peru ve Şili başkanlık sistemi uygulayan üniter devletlerdir.

3. Belli bir süre için seçilen yürütmenin yasamanın güvenine dayanmaması. Parlamenter sistemde yürütmenin gerek iktidara gelirken gerek iktidarı sürdürürken yasamanın güvenini kazanması ve sürdürmesi zorunluluğu vardır. Başkanlık sisteminde ise, başkan doğrudan halktan meşruiyet almış bir yürütme organı olduğu için ne başlangıçta ne de devamında böyle bir zorunluluk vardır. Türkiye'de II. Meşrutiyet döneminde hükümetin sorumluluğunun padişaha karşı olmaktan meclise karşı olmaya dönüşmesine bağlı olarak, denetlenmeyen bir organın keyfiliğe kayacağı korkusu vardır. Amerikan sistemi içinde böyle bir ikilem yoktur. Belirli bir sürenin sonunda halkın değerlendirmesine, yani seçime girecek bir yapı olarak yürütmeye karşı bir önlem düşünülmesine gerek duyulmamıştır. Politik sorumluluk seçmene karşıdır. Ancak belirtmek gerekir ki, başkanın anayasaya, yasalara ve yargıya saygı gösteren bir tutum sergileyeceği siyasal kültürün bir özelliğidir.

Tekrar etmek gerekirse 4 yıllık süreyle kendisine teslim edilen yetkiyi, başkanın kullanma hakkı kabul edilmekte ve örneğin üst düzey bürokrasiye yapacağı atamalar onun hakkı olarak görülmektedir. Ancak belirtilmesi gereken bürokrasinin de hukukla bağlı bir yetki kullanım alışkanlığı olduğudur. Bürokrasinin siyasal güce karşı korunmasından ise söz edilmemektedir. Bu da siyasal kültürün bir parçasıdır. Bürokrasi başkanla birlikte gelir ve başkan değişince gider.

\section{Türkiye'de Başkanlık Sistemi İstenmesinin Tartışılması}

Türkiye'de başkanlık sistemi tartışmaları, 1980'li yılların ortasından beri sürmektedir. “ Geçmişte dönemin cumhurbaşkanı Turgut Özal ve günümüzde başbakan Recep Tayyip Erdoğan'ın başkanlık sistemine yönelik beyanları örnek olarak verilebilir. Dokuzuncu Cumhurbaşkanı Süleyman Demirel'in Cumhurbaşkanını halkın seçmesi yönündeki görüşünü değişik zamanlarda ifade etmesi de buna eklenebilir’(Hakyemez, 2012: 271).

1982 Anayasası parlamenter bir hükümet sistemini benimsemekle beraber, genel olarak yürütmeyi güçlendirerek ve özel olarak da cumhurbaşkanının yetkilerini klasik parlamenter 
sistemden daha farklı düzenleyerek sistem tartışmalarının başlamasına neden olmuştur. Hatta bu anayasanın getirdiği sistemin parlamenter sistem olup olmadı̆̆ı tartışılmıştır. (Turhan, 1989)

1982 Anayasası'nın ilk halinde cumhurbaşkanının yetkilerinin arttırılmış olması parlamenter sistemi sorgulanır hale getirmişse de anayasa hukuku ve siyaset bilimi alanında yapılan çalışmalarda Türkiye'de parlamenter bir rejim olduğu fikri kabul görmüştür. Ancak 2007 yılında Cumhurbaşkanlığı seçimi sırasında ortaya çıkan kriz ve sonunda cumhurbaşkanının halk tarafından seçileceği yönündeki anayasa değişikliği bu tartışmayı yeniden gündeme taşımıştır.

2007 yılının Mayıs ayında TBMM tarafından gerçekleştirilen cumhurbaşkanlığ 1 seçimi sonlandırılamamıştır. Türkiye cumhurbaşkanını seçememiştir. Bunun üzerine 31 Mayıs 2007 tarihli bir anayasa değişikliğiyle cumhurbaşkanını halkın seçeceği bir düzenleme TBMM tarafindan kabul edilmiş, ancak bu değişikliğin halkoylaması 21 Ekim 2007'de gerçekleşmiş ve kabul edilmiştir. Yeni duruma göre cumhurbaşkanını halk seçecektir. Fakat halkoylaması öncesi, 22 Temmuz 2007 seçimlerinde oluşan TBMM bir cumhurbaşkanı seçmiştir. Dolayısıyla 21 Ekim 2007 halkoylaması sonucu oluşan durumun uygulanması ancak 14 Ağustos 2014 tarihinde göreve başlayan cumhurbaşkanı seçiminde uygulanmıştır.

Bu durumda 2014 yılı cumhurbaşkanlığı seçimiyle birlikte ortaya çıkan durum hükümet sistemi olarak nasıl adlandırılacaktır. Bu konuda bir tartışma için (Gözler, 2015: 308-314)e bakılabilir. $\mathrm{Bu}$ rejimin yarı başkanlık rejimi olarak adlandırılması muhtemeldir. Yarı başkanlık rejimi devlet başkanını halkın seçtiği bir parlamenter sistem ise bu görüş doğru olacaktır. Ancak 1980 yılında yayınladığı bir makalede halkın seçtiği bir cumhurbaşkanına sahip Avusturya'yı Fransa'nın yarı başkanlık sisteminden farklı olarak parlamenter diye niteleyen Duverger'i, (1980) izleyerek bu rejime parlamenter demeye devam edeceğiz. Çünkü "2007 anayasa değişikliği, cumhurbaşkanının sadece seçim şeklini değiştirmiş, yetkilerini ve bakanlar kurulu ile ilişkilerini düzenleyen hükümlerde en ufak bir değişiklik yapmamıştır. Bir hükümet sisteminin yarı başkanlık sistemi olarak nitelendirilip nitelendirilemeyeceği, sadece cumhurbaşkanının seçilme yöntemine değil, anayasal yetkilerinin kapsamına da bağlı bir husustur. Nitekim Avrupa'da cumhurbaşkanının halkça seçildiği fakat anayasal konumunun tamamen sembolik ve temsili olduğu birçok ülke vardır ve bunlar, bütün siyaset bilimciler tarafindan parlamenter rejimler olarak değerlendirilmektedir”(Özbudun, 2016: 228). 
Şimdi başkanlık sistemine ve “Türk Tipi Başkanlık” sistemi önerisine dair tartışmalara geçebiliriz. Bu tartışma iki soru çerçevesinde ele alınabilir: 1) Türkiye bir hükümet sistemi değişikliği gereksinimi içinde midir? 2) Öyle ise hangi hükümet sistemi Türkiye’ye uygundur?

Türkiye'nin başkanlık rejimini tartışmaya 1980'lerin ortasında başladığını daha önce belirtmiştik. Buradan çıkan sonuç, 12 Eylül sonrası dönemin Türkiye’nin hükümet sistemini değiştirmesi gerektiğini düşünenlerin hukuken ve fiilen başarılı olamasalar bile, bir gündem yaratmayı başardıklarıdır. Bunun altında yatan neden 1980 sonrası dünyada gelişen küreselleşme eğiliminin gerektirdiği güçlü iktidar modelinin yankılarıdır(Güney, 2007: 345). Sözü edilen güçlü iktidarı sağlamanın en kolay yolunun başkanlık sistemi olarak benimsendiği görülür.

Başkanlık sisteminin en iyi işleyen örneği olan ABD modelinin benimsenmesi beklentisi Türkiye'de karşılık bulmamıştır. Çünkü Türkiye'nin hükümet sistemi arayışındaki güdü temel olarak başkanlık sisteminin etkin bir hükümet olarak düşünülmesidir. Türkiye'nin siyasal kültürü padişah, ebedi şef, milli şef gibi etkili tek adam dönemlerinin etkili olduğu tarihsel bir geçmişten etkilenmektedir. Böyle bir tek adam ya da güçlü lider modelini çok partili siyasal yapı içinde gerçekleştirmenin tek yolunun belli süre için değişmeden kalacak olan başkan olduğu açıktır. Çünkü Türkiye'de siyasal istikrar tek bir partinin iktidarda olduğu koalisyon dışı dönemler olarak algılanmaktadır.

Tek partinin iktidar olduğu dönemlerin çeşitli açılardan başarılı olup olmadığı tartışmasını bir kenara bırakarak, başkanlık sisteminin ve Türk tipi başkanlık sisteminin kabul edilemezliği fikrine bakalım. Yazıcı (2011), Tosun ve Tosun (1999), Polatoğlu (2013), Sözen (2013) ve Çelik' ten (2013) hareketle Türkiye'de siyasal kültürün yönetimin kişiselleşmesine ve otoriterleşmesine eğilimli olması; demokrasiye dönük taleplerin seçimle sınırlı olması nedeniyle başkanlık sistemi uygun görülmemektedir. Özellikle Yazıcı $(2011,166)$ tarafından belirtildiği gibi böyle bir sistem Türkiye'de solun hiç bir zaman iktidar olamayacağı bir sistem olacaktır. 1950'den günümüze seçim sonuçları sol seçmenin \%40’larda kaldığını göstermektedir. Buradan çıkarılacak sonuç, hükümet istikrarını belki sağlayacak yeni sistemin, ülkenin en büyük ikinci seçmen kitlesine sahip bir sol partinin adayının asla başkan seçilemeyecek olmasıdır. Bu durum siyasal sistem istikrarını daha büyük bir tehlikeye 
sokabilecektir. Çünkü demokrasinin önemli özelliklerinden biri de muhalefetteki bir partinin iktidar olma olasılığının devam etmesidir.

Burada kısaca hükümet sistemleri tartışmalarından daha önemli gördügümüz demokrasi sorununa odaklanacağız. Öncelikle Türkiye'de demokrasinin önünde engel olarak görülen birkaç soruna değineceğiz. Sonra yeni anayasa yapma gerekliliğinin yanında, toplumun uzlaşması sonucu yapılabilecek bir anayasanın prosedürel gerekliliklerine değineceğiz.

1) Türkiye'de demokrasinin gerçekleştirilememesinin önündeki en büyük engel siyasal kültürümüzde demokrasinin yokluğudur. Demokrasi yönündeki talepler yaygın olarak demokrasinin ne olduğu yönünde bir bilgi eksikliğiyle maluldür. Hem bireysel düzeyde insanların demokrasi kavramını ve kültürünü içselleştiremediğini, hem de siyasal partiler dâhil örgütlerde de demokrasi kavramı, kültürü ve pratiğinin eksik olduğunu görüyoruz. Burada en açık örnek siyasal partiler yasasının ve siyasal partilerin kendi örgütsel etkinliklerinin demokratik uygulamalardan yoksun olmasıdır. Literatürden bir kavram kullanmak gerekirse “oligarşinin tunç yasası” parti örgütlerinde yaygıı olarak gözlenebilmektedir.

2) Ülkenin ekonomik sorunlarının, özellikle milli gelir düşüklüğünün ve gelir dağılımı adaletsizliğinin demokrasi açısından büyük bir sorun olduğunu görüyoruz. Seçmen yurttaşın oyu içinde bulunduğu ekonomik olanaksızlıklar dolayısıyla kolayca manipüle edilebilmektedir.

3) Tarihsel geçmişimizin özgürlükçü, eşitlikçi ve laik bir kültürü beslemediği görülür. $\mathrm{Bu}$ çerçevede demokrasinin gerekliliği olan dünyevi düşüncenin ve eşitlikçi kültürün gelişmesini sağlayacak düşünce özgürlüğü ve tartışma (müzakere) pratiklerinin eksikliği dikkat çekicidir. Örnek olarak parti liderlerinin taraftarlarına hitapları ve kamuoyu önünde diğer parti liderlerine yönelik hitap ve eleştiri üslupları verilebilir.

4) Literatürde yaygınlaşmaya başlayan bölünmüş toplum kavramı kapsamında Türkiye'nin çalışma konusu yapıldığını görmekteyiz. Örneğin yakın zamanlarda yayınlanmış bir çalışmada Türkiye'yi inceleyen Bora Kanra, çalışmasının başlığını bölünmüş toplumlarda demokrasi olarak koymuştur. Türkiye'nin bölünmüş toplum sayılmasının başlıca nedeni tahmin edebileceğimiz gibi; etnik, dinsel, mezhepsel, dilsel, bölgesel ve bunlar üzerine oturtulmuş politik örgütlenmelerdir. Bu bölünmüşlük durumunun grup üyeleri üzerinde yarattı̆ğ etkiler 
zihniyette yarattığı farklılaşmalar ölçüsünde bir arada yaşamanın tartışılmasına yol açmaktadır. Türkiye'de çok saygın bir sosyal bilim dergisi olan Toplum ve Bilim'in son yıllardaki temel tartışma konularından birisi “Türkiye toplumunu bir arada tutan nedir?" sorusuyla formüle edilmiştir ve tartışma sürmektedir." $\mathrm{Bu}$ sorunun çağrıştırdığı ilk şey "toplum neden dağılmiyor"dur?

5) Seçim sisteminin demokratik bir temsil oranını yansıttığı tartışmalıdır. Ancak partiler bu konuda düzenlemeler yapma konusunda çok istekli değildirler. Çarpık temsil diyebileceğimiz ve iki seçim döneminde açıkça görülmüş olan temsilde adaleti sağlamayan seçim sisteminden vazgeçilmediğini görüyoruz. Buradan çıkardığımız sonuç, baraj altında kalarak yaklaşık \%10 oy oranı ile parlamentoda temsil edilemeyen siyasal partiler dahi az oyla yüksek temsil sırasının kendilerine de geleceğini düşünerek bu seçim sisteminin sürmesini kabul ediyorlar. Örneğin 1987 genel seçiminde ANAP \% 36 oy \% 65 sandalye oranına; 2002 genel seçiminde AKP \%34 oy \% 65 sandalye oranına sahip olmuştur. Özellikle 2002 genel seçiminde \%45'ten fazla seçmen oyu parlamentoya yansımamıştır.

6) Parti içi demokrasi kültürünün yokluğu siyasal partilerde lider sultasına yol açmakta ve liderler uzun y1llar partilerinde her konuda tek belirleyici haline gelmektedir. $\mathrm{Bu}$ durum partilerin kendi yapılarında ve ülkenin siyasal yapısında değişimi engelleyici bir rol oynamaktadir.

7) Siyasal parti liderlerinin demokrasi ve milli irade kavramına yükledikleri anlam da demokrasinin gelişmesi önünde bir engeldir. Çoğulcu olmayan çoğunlukçu bir demokrasi ve milli irade kavrayışı bir çarpıklığa yol açmaktadır. Çünkü çoğunluk bile seçmenlerin çoğunluğu ile sınırlı iken, parlamento çoğunluğunu elde eden partiler sadece parlamentoya odaklanarak bir dahaki seçime kadar seçmen çoğunluğunu unutmaktadırlar. Yani seçmenin \%35 oyu ile parlamentoda \%65 çoğunluk kazanan parti seçmenin \%65 çoğunluğunu dikkate almamaktadır; toplumda uzlaşma aramamaktadır.

\footnotetext{
* Toplum ve Bilim dergisinin 2009 yılında yayınlanan 115. Sayısında "Gelecek sayımızdan itibaren, "Türkiye toplumunu birarada tutan nedir?” sorusu etrafında bir tartışmayı örmeye başlamayı umuyoruz" çağrısıyla birçok sayı sürmesi beklenen bir dosya konusu belirlendiği duyurulmuştur. Niteki 116, 117, 118 ve 119. Sayılarda bu dosya kapsamında yazılar ve görüşler yayınlanmıştır.
} 
8) Son olarak merkezi yönetimin güçlülüğüne dayalı siyasal kültürümüze göre şekillenen politikalar, halkın katılımı çerçevesinde çözülmesi gereken yerel, bölgesel ve çevresel sorunlar çözümünde halkı dışlamaktadır. Özellikle son yıllarda çok karşılaştığımız madencilik ve barajlarla ilgili ortaya çıkan çevre sorunları yerel halkı sistemle çatışır konuma sürüklemektedir. Bu durum da uzlaşma anlayışını azaltmaktadır.

Şimdi yukarıda sözü edilen, tüm sorunların çözümünde etkili olacağı iddiasıyla yapılmak istenen yeni bir anayasanın, sorunları artırıcı olmayan bir yöntemle yapılabilmesi için prosedürel bir öneriyle bitirebiliriz.

Anayasa yapım süreciyle ilgili literatürde kabul görmüş yaklaşım bir kurucu iktidarın anayasa yapma hakkı olduğudur. Kurucu iktidarın tanımlanması ve ortaya çıkması ise bir olağanüstü hale bağlanmaktadır. Savaş, yeni kurulan veya bağımsızlığını yeni kazanan bir devlet, ya da bir darbe veya devrim sonrası ortaya çıkan güç kurucu iktidar olarak yeni bir anayasa yapabilir. $\mathrm{Bu}$ tartışma çerçevesinde kurulu iktidar sayılan olağan parlamentonun yeni bir anayasa yapamayacağı kabul edilmektedir(Gözler, 2015:20-25).

Türkiye'de anayasa tartışmalarının hep gündemde kaldığı görülüyor. TBMM'de sağlanan uzlaşmanın genellikle düşük düzeyde kalmasının ötesinde yapılan referandum sonuçlarındaki oy farkının çok düşük olması da bu tartışmanın bitmemesinde etkili oluyor.

\section{Sonuç Ve Öneriler}

1) Türkiye'de 1982 anayasasının yürürlüğe girdiği günden bu yana, halkın, siyasilerin ve entelektüellerin 30 yılda oluşturdukları ortam bir olağanüstülük arayışına yer bırakmadan bu anayasanın değiştirilmesine hazır. Toplumun büyük çoğunluğu tümüyle yeni bir anayasaya ihtiyaç olduğunda hemfikirdir(Özbudun, 2016: 222). Ancak toplumsal gruplar anayasanın yapım sürecinden kendilerinin tatmin olacağı bir sonuç çıkmamasından korkuyor. Öyle ise bu korkuyu aşmak için ne yapılmalıdır. 
2) Hiç kimsenin temsilinde dışlanmayacağı özel misyonlu, anayasa yapım sürecinin tamamlanmasından sonra dağılacak $100^{* *}$ üyeli bir kurucu meclis kurulmalıdır. Bunun için kurucu meclis oluşumu için baraj içermeyen ve çok sayıda siyasal partinin katılabileceği bir seçim yapılmalıdır.

3) $\mathrm{Bu}$ meclisin 100 üyesi için seçime katılan her parti sıralı 100 kişilik bir aday listesi vermelidir. Bu aday listeleri, 20 partinin katılacağı bir seçimde 2000 kişiyi bulmaktadır. $\mathrm{Bu}$ rakam Türkiye'de anayasa yapım sürecinde bulunması gerekir diye düşünülebilecek her türlü uzmanlık ve temsil gücünü yansitabilecek bir rakamdır. Bu seçimin sonucunda partiler aldıkları her $\% 1$ oy dilim için 1 adayını kurucu meclise gönderecektir. Böylece her seçmen kendi temsilcisini kurucu mecliste görecektir.

4) Oluşan kurucu meclis ilk toplantısında demokrasinin gelişmiş olduğu, Türkiye'nin de kendisini içinde gördüğ̈̈ demokratik dünyanın değerleriyle kendisini kısıtlama kararı alarak çalışmaya başlayacaktır. Bu değerler, çoğulculuk, eşitlik, özgürlük, laiklik, hukuk devleti gibi değerler olacaktır. Bu değerleri dikkate alarak ve her türlü müzakereyi yürüterek, ülkenin uygulayacağı hükümet sistemi de dâhil olmak üzere, yeni bir anayasayı 3/4 oy çokluğuna dayalı bir sistemle ve sistematik bir bütünlük içinde 100 günde tamamlar. Bu anayasa referandum yoluyla toplumun yeniden onayına sunulur ve kurucu meclis kendiliğinden dağılır.

5) Yeni anayasal sisteme göre tekrar belirlenmek üzere olağan görevlerini sürdürmekte olan parlamento seçime gider.

\footnotetext{
** $\mathrm{Bu}$ sayı mutlak bir sayı olarak değil, toplumun \%100 temsil edilirliğinin simgesel bir ifadesi olarak düşünülmüştür.
} 


\section{Kaynakça}

Ağaoğulları, Mehmet Ali (2004) Kent Devletinden İmparatorluğa, Ankara: İmge Kitabevi Yayınları, 4. Baskı.

Çelik, Demirhan Burak (2013) "Parlamenter Geleneğimiz, Otoriterleşen Demokrasimiz ve Türk Tipi Başkanlık Sistemi”, Cogito, Sayı 74, Yaz 2013. (201-212)

Duverger, Maurice (1980) “Yeni Bir Siyasal Sistem Modeli: Yarı Başkanlık Hükümeti”, (çev.

Mehmet Turhan), Devlet ve Hukuk, Mehmet Turhan içinde. (68-97), Ankara: Gündoğan Yayınları.

Eroğul, Cem (2008) Çağdaş Devlet Düzenleri, Ankara: İmaj Yayınları.

Eroğul, Cem (2005) Anatüzeye Giriş, Ankara: İmaj Yayınları.

Gözler, Kemal (2015) Anayasa Hukukuna Giriş, Bursa: Ekin Yayınları.

Gözler, Kemal (2013) Anayasa Hukukunun Genel Esasları, Bursa: Ekin Yayınları.

Gözübüyük, Şeref (2011) Anayasa Hukuku, Ankara: Turhan Kitabevi.

Gülalp, Haldun (2013) “Sunuş: Başkanlık Sistemi Tartışmaları”, Cogito, Sayı 74, Yaz 2013. (195-200)

Güney, Atilla (2007) “Sonuç Yerine: Türkiye'de Başkanlık Sistemi Neden Tartış1lıyor”, Başkanlık Sistemi ve Türkiye (Derleyen İhsan Kamalak), İstanbul: Kalkedon Yayıcılık.

Hakyemez, Yusuf Şevki (2012) “Hükümet Sistemi Arayışları ve Yeni Anayasa”, Demokratik Anayasa, Ece Göztepe ve Aykut Çelebi (Hazırlayanlar), İstanbul: Metis Yayınları. (270-297)

Kaboğlu, İbrahim (Derleyen) (2016) Türkiye’nin Anayasa Gündemi, İstanbul: İletişim Yayınları.

Kalaycıŏ̆lu, Ersin (2005) “Başkanlık Rejimi: Türkiye’nin Diktatörlük Tehdidiyle Sınavı”, Başkanlık Sistemi, Ankara: TBB Yayını.

Kanra, Bora (2013) Türkiye'de Demokrasi, İslam ve Diyalog Bölünmüş Toplumlarda Müzakere, İstanbul: Bilgi Üniversitesi Yayınları.

Kuzu, Burhan (2012) Her Yönü İle Başkanlık Sistemi, İstanbul: Babıali Kültür Yayıncılığı.

Özbudun, Ergun (2016) "Cumhurbaşkanının halk tarafından seçilmesi, sistemi dönüşüme uğratmış mıdır?, Türkiye'nin Anayasa Gündemi, Kaboğlu, İbrahim (Derleyen), İstanbul: İletişim Yayınları. (222-228) 
Polatoğlu, Aykut (2013) “Başkanlık Sistemi ve Türkiye'de Uygulanabilirliği Üzerine Düşünceler”, YDÜ Sosyal Bilimler Dergisi, Cilt 6, Say1 1, Nisan 2013.

Sözen, Yunus (2013) "Demokrasi ve Otoriterlik Arasında: Başkanlık Sistemine Geçiş Siyaseti”, Cogito, Sayı 74, Yaz 2013. (213-233)

Teziç, Erdoğan (2001) Anayasa Hukuku, İstanbul: Beta Yayınları.

Tosun, Tanju ve Gülgün Erdoğan Tosun (1999) Başkanlık ve Yarı Başkanlık Sistemleri, İstanbul: Alfa Basım Yayım Dağıtım.

Turhan, Mehmet (1989) Hükümet Sistemleri ve 1982 Anayasası, Diyarbakır: Dicle Üniversitesi Hukuk Fakültesi.

Uluşahin, Nur (1999) Başkanlık Sistemi, Ankara: Yetkin Yayınları.

Uygun, Oktay (2014) Devlet Teorisi, İstanbul: On İki Levha Yayınc1lık.

Yazıcı, Serap (2011) Başkanlık ve Yarı-Başkanlık Sistemleri, İstanbul: İstanbul Bilgi Üniversitesi Yayınları. 